\title{
Review of Zoya G. Proshina and Anna A. Eddy (eds.). 2018. Russian English: History, Functions, and Features. Cambridge: Cambridge University Press. 309 p. + xvii p.
}

\author{
Elena V. MARININA \\ Lomonosov Moscow State University \\ Moscow, Russia
}

For citation:

Marinina, Elena V. 2020. Review of Zoya G. Proshina and Anna A. Eddy (eds.). 2018. Russian English: History, Functions, and Features. Cambridge: Cambridge University Press. 309 p. + xvii p. Russian Journal of Linguistics 24 (3). 722-729. DOI: 10.22363/2687-0088-2020-243-722-729

Рецензия

\section{Рецензия на монографию Zoya G. Proshina and Anna A. Eddy (eds.). Russian English: History, Functions, and Features. Cambridge: Cambridge University Press, 2018. 309 c.}

\section{Е.В. МАРИНИНА}

Московский государственный университет имени М. В. Ломоносова Москва, Россия

\section{Для цитирования:}

Marinina E.V. Review of Zoya G. Proshina and Anna A. Eddy (eds.). 2018. Russian English: History, Functions, and Features. Cambridge: Cambridge University Press. 309 p. + xvii p. Russian Journal of Linguistics. 2020. Vol. 24. № 3. P. 722-729. DOI: 10.22363/2687-00882020-24-3-722-729

World Englishes, i.e. numerous varieties of the English language, their statuses, and their legitimacy (Proshina 2016), present some of the most interesting, important, and at the same time, controversial issues of modern linguistics and adjoining disciplines, such as sociolinguistics, pragmalinguistics and linguacultural studies. It should be emphasized from the very outset that though quite a number of varieties of English have been already researched, described, and analyzed, Russian English: History, Function, and Features is the very first attempt to give a detailed description of Russian English, a specific "European or, to be precise, a Eurasian variety" (p. 1) of English. 
Another point to be mentioned is that the book presents the views, ideas and approaches of the best known and most authoritative experts in the field. Taking into consideration that the authors live and work not only in Russia but in some other countries, it may be presumed that the work is a comprehensive overview of the state of the art in the domain of world Englishes in general, and of Russian English, in particular.

This edited work is a brave - and successful - attempt to give a positive answer to an all-important, fundamental question formulated in the title of an earlier paper on the subject: "Does Russian English exist?" (Bondarenko 2014). Russian English presents a complicated object for linguistic research since Russia is a multi-ethnic and multicultural country. This complexity is reflected in the wide range of subjects and approaches covered in different parts and chapters of the book. In order to understand the nature of any linguistic phenomenon, including languages and their varieties, it is absolutely necessary to analyze its history and development. In order to do this, Anna Eddy and Zoya Proshina present a comprehensive overview of Russian-English language contacts from the $16^{\text {th }}$ century till now, showing the peculiarities of each particular period.

The authors provide their answers to two fundamental questions. The first question is: what is meant by "Russian" in the collocation "Russian English"? This adjective may denote the specific ethnicity and at the same time it can refer to all ethnicities of the Russian Federation. In the second case, we can speak of Russian Englishes that will be different from each other mainly in terms of culture-related words. The second question is: who may be considered to be a user of Russian English? It is an all-important question for selecting material for research in the field of Russian English.

In the second chapter, "Russian English in the family of World Englishes," Zoya Proshina concentrates on the methodological and terminological basis for singling out and discussing the phenomenon of Russian English. The author suggests considering the Russian variety of English as consisting of: "the acrolectal Russia (or Russia `s) English as a formal kind of the variety, typical of governmental documents, mass media, ... diplomats, well-educated scholars, etc.; mesolectal Russian English as a less formal and more casual subtype or a subtype of less educated speakers, and basilectal Ruslish also known as Runglish or Renglish, a subtype used by speakers, and writers with low language competence" (p. 27). These subtypes of Russian English differ functionally, stylistically, and situationally.

The key notion for the whole monograph is variety. Proshina defines it as "a social performance continuum that is formed from individual idioms typically and systematically produced by bilingual speakers" (p. 28). Another important characteristic of a non-native variety is the fact that its distinctive features contain not only deviations from exonormative models but also innovations, i.e. "cultureloaded words borrowed by English from an indigenous language" (p. 28). Having discussed the important theoretical and terminological points mentioned above, 
Proshina gives the definition of Russian English. It is "a variety of English used by bilingual Russians to express their cultural identity and implement other communicative goals" (p. 28).

Chapter 3 "Russian English Linguaculture" is presented by a group of authors (Zoya Proshina, Alexandra Rivlina, Svetlana Ter-Minasova, Elena Beloglazova, and Victor Kabakchi). This part of the monograph aims at providing a typological comparison of English and Russian and showing those features of the two languages that may influence Russian English. The authors compare English and Russian in terms of morphology, syntax, vocabulary, and phonetics. Accurate and detailed descriptions of Russian and English are provided to explain and foresee the potential problems and difficulties Russian users of English may face, and to show the ways in which the Russian language may influence Russian English. The influence of Global English on Russian may be traced mainly in the development of analytical features, gradual loss of inflections, and increase in the use of informal style features. It is mentioned, that though widely spread, "Englishization" of Russian remains one of the most controversial and debated topics in Russia.

Numerous instances of the heavy influence of English on modern Russian are analyzed in terms of grammar, vocabulary, phonetics/phonology, graphic arrangement and punctuation features, pragmatic and discoursal features, even nonverbal behavior. The long list of linguistic, sociolinguistic, and pragmalinguistic functions of English-Russian code-switching and code-mixing supports the central idea of the book that Russian English has the status of a variety, as other Englishes of the Outer and Expanding Circles do. Another important point is the changes in Russian culture and Russian mentality caused by a heavy influence of English on the Russian language, culture, and life in different spheres. The final part of the chapter is devoted to the ways Russian culture is introduced to the world through the English language.

Chapter 4, "Linguistic Features of Russian English" (Victoria Zavyalova, Zoya Proshina, Anna Ionina, Anna Eddy, and Tatiana Ivankova), gives the most detailed and comprehensive overview of performance trends typical of many (but not necessarily all) educated Russian users of the English language. Having discussed the linguistic peculiarities of Russian English, the authors pass on to the discussion of the pragmatic features of Russian English, the most important and noticeable of them are:

- politeness;

- imperativeness;

- masculine orientation;

- belittling oneself.

In the following chapters (from 5 to 8 ) the authors consider the functioning of English in various fields in Russia. The first domain is politics; it is quite reasonable because it is in this field that the most important changes have taken place in the last decades. Having analyzed texts from two political journals and an interview with Sergey Lavrov, the Russian Foreign Minister, Tatiana Ivankova and Elena 
Salakhyan make insightful observations about some characteristics of Russian political discourse (unclarity, vagueness, and fuzziness of expression). However, the choice of George Orwell`s essay "Politics and the English Language" (1946) as the starting point for the research may seem disputable.

Another sphere where English plays a very important part in modern Russia is business (Chapter 6 by Irina Krykova \& Olesya Lazaretnaya). It may be even said that professional English is viewed as a symbol of status. A large number of loan words came into Russian through business English: however, a great number of such borrowings are not always justified and may cause a negative attitude in the society.

Analyzing the functioning of Russian English in the field of education (Chapter 7), Galina Lovtsevitch starts with a brief review of the history of ELT in Russia, where English has been an essential part of secondary and higher education since the 1930s. The author pays special attention to the review of the textbooks used for ELT in the 1970s and 1980s; they were mainly based on British English. The author proceeds with the changes brought by Perestroika, when English acquired practical value for learners. The Common European Framework and communicative competence came to the fore. In 2009, the Ministry of Education introduced the National Unified Exam (EGE) for secondary schools.

One of the fundamental questions in ELT in Russia nowadays is what variety should be taught. Students are well aware of British English and American English models. However, the questions are bound to arise: "Is there a need to get rid of one's Russian accent? Isn't the role of English in intercultural communication to express the Russian identity of the speaker and to spread information about Russian culture?” (p. 147).

In Chapter 8, "Scholarship," Elena Lawrick shows how English is gaining a competitive advantage in the modern Russian academic environment due to the policy of modernization of the science sector. English is widely used for international publications, but it should be noted that Russian scientists have a lot of difficulties in getting published, mainly because of "low proficiency in academic English and insufficient familiarity with the genre of Western-style research publication" (p. 151).

Another domain where English is widely used in Russia is mass media (Chapter 9 by Anna Eddy, Tatiana Ivankova, and Elena Lawrick). The presence of the English language is especially noticeable on TV, where there was an increase in the use of English during the post-perestroika period. Many Russian TV programs are versions of American and British productions, and their hosts try to imitate the original linguistic patterns and the pronunciation of proper names. A great number of English-language channels are now available, including a 24-hour English-language channel Russia Today.

The authors proceed with providing a comprehensive overview of the English language media in Russia: television, the radio, newspapers, magazines, websites aimed at either global readership, viewers, and listeners, or Russian learners of 
English. It is important to underline that English-language media in Russia demonstrate different varieties of English: British, American, Russian and other World Englishes.

The field where English has always played a very important role in Russia is tourism (Chapter 10 by Olesya Lazaretnaya). The author analyzes the changes in the use of English as the major means of communication in tourism, which have been taking place since 1929, when the Intourist Agency was founded. The most important and the most interesting conclusion is that nowadays Russian tourists and Russian learners of English are exposed not only to British and American English but to a great number of local varieties of English spoken in different countries.

Other domains where the English language started to have an important, though rather controversial, role due to the influence of Western culture and its values of consumerism are pop culture, entertainment and club culture, the music subculture, extreme sports, and such social groups as young people, gays and lesbians, and music fans (Chapter 11). Anna Eddy provides a careful analysis of the use of English as a medium of communication, self-expression, a signal of status and identity, and even as a marketing device among people belonging to the cultural and social groups mentioned above.

Chapter 12 deals with advertising. Irina Ustinova gives a comprehensive overview of Russian advertising discourse that is characterized by a heavy influence of the English language manifested in code-mixing, code-switching and code-play in all elements of an advertisement layout. Having described the formal characteristics and structural patterns of advertising texts, the author passes on to the functions performed by the English language in this domain. The most important ones are: being a marker of prestige, promoting Western products, creating innovative and attention-getting effect; last but not least, transmitting typical American values.

Chapter 13 addresses literature, which may seem to be rather unexpected in terms of Russian English. However, Evgenia Butenina provides the reader with a thorough analysis of works written by writers who are Russian in origin but who write in English. The author concentrates on Russian-American literature, starting with Vladimir Nabokov. Obviously, there are numerous differences in attitudes, approaches, and styles among the authors: the elusive secret code of Vladimir Nabokov; the elitist code of Olga Grushin; the carnivalesque discourse of Vassily Aksyonov; the satire and parody of Gary Shteyngart and Anya Ulinich; literary Russianness as a strategy of seduction in the writing of Lara Vapnyar and Irina Reyn; the realist mode of David Bezmozgis and Ellen Litman. All of these writers have brought Russian cultural codes, concepts, and values into American literature.

Of special interest is the last part of the book, "Attitudes of Russian Speakers toward Russian English." In Chapter 14, "Competition with Russia as an International Language," Irina Ustinova gives an insightful and detailed analysis of the changes in the status, spread, and functions of the Russian language that have been taking place since the 1990s, after the collapse of the Soviet Union. In Chapter 
15, "Linguistic Purism," Olesya Lazaretnaya deals with a wide range of questions. The author describes in detail the reaction of the Russian government and other official bodies to the uncontrolled influx of English borrowings and the excessive, and not always justified, influence of the English language on Russian in the 1990s. Russian linguists emphasize the negative influence of mass "Americanization" not only on Russian vocabulary but also on rhythmical structures and intonation patterns. On the other hand, some scholars are more optimistic, and consider the extensive use of English loan words by Russian young people to be just a popular trend. It is shown, however, that the reaction of Russian people is different and depends on the area they live in. The author concludes by stating that fears about the future of the Russian language are unfounded, since it remains a symbol of national culture and national identity.

In Chapter 16, "Resistance to and Gain in the World Englishes Paradigm," Zoya Proshina and Irina Ustinova concentrate on the concept of Russian English, its status and various attitudes from scholars and the society. It is worth mentioning that the first publications on different regional varieties of the English language, later known as World Englishes, appeared in the Soviet Union at the beginning of the 1960s. Nowadays most works are connected with Asian Englishes for obvious economic, political, cultural reasons. However, at the beginning of the $21^{\text {st }}$ century there appeared investigations of the variety of English used in Russia by such scholars as Zoya Proshina, Irina Ustinova, Alexandra Rivlina, Anna Eddy, Elena Lawrick, and Olesya Lazaretnaya. It is interesting to note that most of the researchers avoid using the term "Russian English" because its status remains rather vague in linguistics in Russia. It is used sometimes to denote the most common errors and mistakes made by Russian speakers of English. It should be noted, however, that according to the latest research, the attitude of society in Russia to the idea of Russian English is becoming more positive.

Chapter 17 (Maria Lebedko) describes the functions performed by the English language in one of the Russian regions, Tuva. The author argues that in this republic of Russia, English serves as a secondary means for self-identity, since several dictionaries of Tuvan language and culture have already been published in English. There can be no doubt that publishing culture-loaded words in the global language dictionary is a very good way to make the unique and rich Tuvan culture known to the world.

In the afterword of the volume, Zoya Proshina provides a well-structured and cogent overview of the ideas expressed by the chapter authors. She starts with a definition of Russian English as "a performance variety of the educated Russians who mostly learn it through education in an artificial language setting" (p. 258). It is important to emphasize that Russian English should not be equalized with Ruslish, "a pidginized hybrid formation used by non-educated Russians" (p. 258). The author proceeds with a brief description of the main distinctive features of Russian English on all levels of linguistic analyses; the results of the mutual influence of the English and Russian languages; the functions performed by the 
English language in Russian politics, business, education, mass media, tourism, literature. In conclusion, Zoya Proshina expresses the firm belief of the contributors to the book that though the status of Russian English is still highly disputable, nevertheless, Russian English is a variety of the Expanding Circle.

The collective monograph Russian English is an unprecedented and highly important volume which provides a detailed and comprehensive overview of an Expansive Circle variety of English. The contributors to the book firmly believe that Russian English does exist as a variety of the Expanding Circle. However, there can be little doubt that this idea is not generally accepted yet. The status of Russian English is still disputable for several reasons. Firstly, it is connected with terminological difficulties since the term variety may be understood in different ways. Secondly, the authors admit that Russian English may be understood differently. If we proceed from the assumption that Russian English is a variety used by "minority ethnicities as an additional means for expressing their cultural identity" (p. 263), then we should speak about Russian Englishes. Hence, questions are bound to arise: How many Russian Englishes are there (taking into consideration that there about 60 languages just in the Caucasus)? What are their statuses? Thirdly, it is not quite clear whether the most obvious characteristics of Russian English affect communication with speakers of other first languages and native speakers of English. The fact that the volume poses these important questions and generates discussion of them is, no doubt, one of its real merits.

To conclude, the collective monograph under review may be considered as an important first attempt to produce a comprehensive and overall analysis of Russian English, a highly complex language phenomenon. The results of the investigations will stimulate further research and discussion; they are of great importance to specialists working in the field of general linguistics, contact linguistics, social linguistics, language policy, linguacultural studies, and teachers of English as a Foreign or International Language and a Language for Special Purposes.

(C) Elena V. Marinina, 2020
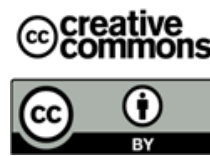

This work is licensed under a Creative Commons Attribution 4.0 International License https://creativecommons.org/licenses/by/4.0/

\section{REFERENCES}

Bondarenko, Olga. 2014. Does Russian English exist? American Journal of Educational Research 2 (9). 832-839.

Proshina, Zoya G. 2016. Legitimacy of Russian English. Procedia - Social and Behavioral Sciences 236. 201-206. 


\section{Book review history:}

Received: 8 May 2020

Revised: 13 July 2020

Accepted: 15 July 2020

\section{История рецензии:}

Дата поступления в редакцию: 8 мая 2020

Дата принятия к печати: 15 июля 2020

\section{Bionote:}

Elena V. MARININA, PhD, Associate Professor, Department of Foreign Language Teaching Theory, Faculty of Foreign Languages and Area Studies, Lomonosov Moscow State University. Research interests focus on English Linguistics, Sociolinguistics, Linguacultural Studies, Intercultural Communication, ELT.

\section{Contact information:}

Lomonosov Moscow State University

1, bld. 13, Leninskiye Gory, Moscow, Russia, 119991

e-mail: emarinina1@yandex.ru

eLibrary SPIN-code: 6992-5433

\section{Сведения об авторе:}

Елена Викторовна МАРИНИНА - кандидат филологических наук, доцент, доцент кафедры теории преподавания иностранных языков факультета иностранных языков и регионоведения МГУ имени М. В. Ломоносова. Научные интересы: английское языкознание, социолингвистика, лингвокультурология, межкультурная коммуникация, преподавание английского языка.

\section{Контактная информация:}

МГУ имени М.В. Ломоносова, факультет иностранных языков и регионоведения 119991, Москва, Ленинские горы, стр. 13

e-mail: emarinina1@yandex.ru

eLibrary SPIN-код: 6992-5433 